\title{
Assessment of action of mutagen factors on formation of quality attributes at mutant generation of lettuce (Lactuca sativa var. secalina L.)
}

Kondratenko S. ${ }^{1}$, Shabetya O. ${ }^{2}$, Mogilna O. ${ }^{3}$, Tkalich $\mathrm{Yu} .^{4}$

${ }^{1-3}$ Institute of vegetable growing and melon production of NAAS, Instytutska Str., 1, Selektsiine, Kharkiv oblast, 62478, Ukraine, ${ }^{4}$ Department of agroindustrial development, ecology and natural resources of Chernihiv OSA, Shevchenko Str., 4, Chernihiv, 14000, Ukraine; e-mail: ' $s e r g-$ kondratenko@hotmail.com,_2shabetyaoksana@gmail.com, 3patentiob@gmail.com, 4tkalichyriy@gmail.com

The purpose. To determine action of mutagen factors on formation of quality attributes determining phenotype of a leaf and to carry out comparative correlation analysis between developing process of quality and quantitative attributes of genotypes of lettuce of mutant origin. Methods. Nonparametric statistics, field assessment, calculation-analytical. Results. Features of action of physical and chemical mutagenesis on phenotypical developing process of quality attributes determining morphology of a leaf of lettuce are fixed. The extent of divergence of developing process of quality attributes depending on action of mutagen factor between target forms and derived from them mutant genotypes is specified. Important correlation for selection process between quality and quantitative attributes at the probed genotypes are established. It is fixed that according to developing process of association marks determining phenotype of leaf blade the most contrast in comparison with initial form were 5 mutant samples which were formed as a result of g-irradiation and treatment of seeds with preparations DMU-1 and DMU- 5 before sowing. Conclusions. The probed correlation enable to select highly productive genotypes of lettuce at early stages of ontogenesis of plants on association of quality attributes determining phenotype of leaf blade. Statistically reliable correlation is especially useful between integrated parameter for aggregate of quality attributes "average index for sampling» and level of attribute "amount of leaves on one plant». On the basis of mutant samples of lettuce new high-yielding variety Patriot which exceeded variety-standard Snizhynka on a complex of valuable quantitative attributes is created. Productivity of new variety makes $11,92 \mathrm{t} /$ hectare against $6,14 \mathrm{t} /$ hectare at the standard one. Amount of days for the period from mass shoots up to commodity maturity at new variety makes $17-18$, while at variety-standard Snizhynka $20-$ 23 days.

Key words: lettuce, blade, quality attributes, induced mutagenesis, correlation. https://doi.org/10.31073/agrovisnyk201811-17

Introduction. Recently, the demand for leaf lettuce has increased significantly in Ukraine, and, as a result, there has been an intensification of breeding work with this green crop. The main task of domestic lettuce breeding is to develop varieties suitable for cultivation in all agro-climatic zones of the country, both in open and protected soils [1, 2]. To develop varieties of this green crop, mainly hybridization is used, followed by individual, group and mass breeding. When developing the majority of modern varieties, hybrid material is used. The technique of lettuce hybridization is quite complicated, it is due to the structure and size of the flower adapted to self-pollination, as well as the biology of flowering [3,4]. It is expedient to use the method of induced mutagenesis as a unique breeding technique for expanding the leaf lettuce gene fund. It should be used in those cases where it is necessary to improve only one important trait, leaving the main gene unchanged.

The analysis of recent research and publications on the topic under study. Many foreign scientists are engaged in the mutagenesis of lettuce, which makes it possible to solve problems of improving the indices of this crop [5, 6, 7]. In breeding, both induced mutagenesis and spontaneous mutants, which often appear in plant populations, are used. In the United States, the search for sources of resistance to the downly mildew was carried out among varieties, breeding and mutant lines obtained by -irradiation. In 
the breeding process, steady forms were found - Grand Rapids variety, Ice berg variety and three mutant lines [8]. According to D. Marcu at el., the greatest effect from the action of mutagenic factors is achieved after their use for the seed treatment $[9,10]$. However, in Ukraine research in this area has been extremely inadequate, and the useful potential of mutagenesis for the lettuce breeding is not completely determined and investigated.

Material and methods of research. In order to expand the spectrum of genotypic variability of the leaf lettuce seedlings(Lactuca sativa var. secalina L.) in 2011, an experimental research on chemical and physical mutagenesis was commissioned on the experimental basis of the Institute of Vegetable and Melon, Growing. As an object of research, the experiment used a variety of leaf lettuce developed at the Institute of Vegetable and Melon Growing of NAAS. To obtain mutant samples, the air-dry seeds of the selected variety were treated with biologically active substances of mutagenic action - dimethyl sulfate (DMS) and preparations DMU-1 and DMU-5 made on the experimental basis of the Bioorganic Chemistry and Petrochemistry Institute of the National Academy of Sciences in Ukraine (Kyiv). This treatment was carried out by presowing plunging into water solutions of preparations at an active concentration of 0,02 $\%$ and at various time exposure treatments (3, 6 and 18 hours). Control - seeds were soaked in distilled water. As a physical mutagen, -irradiation was used, with which pre-sowing treatment of air-dry seeds with doses of 7, 1115 kilograms of -ray (kP) was used. Control - air-dry seeds, which have not undergone -treatment.

The analysis of mutant samples of leaf lettuce concerning the features of manifestation in quantitative and qualitative traits was carried out under field conditions. Field studies were based on the standard methods described in the monographs: "Modern methods of breeding vegetable, water melon, melon and gourd plants" (2001) [11], "Technique of experimental research in vegetable, water melon, melon and gourd growing (2001) [3]. Commonly accepted agrotechnical techniques and methods to grow rare vegetable crops were used and presented in the work.[12].

While analyzing the phenotype of the mutant leaf lettuce forms, their difference from the original variety genotype was identified by association with qualitative traits of the leaf blade, which determine its morphology, vein, edge form and colour. In order to assess the degree of manifestation of the qualitative traits of this organ in mutant genotypes, the methods to examine lettuce varieties (Lactuca sativa L.) concerning difference, uniformity and stability worked out at Ukrainian Institute for Plant Variety Examination (2007) were used, which suggested the corresponding codes (marks) of manifestation of 17 qualitative traits of the leaf to determine the test traits of varieties on the base of VOS test [13]. Among the investigated qualitative traits there are seven that determine the morphology of the leaf blade and the veining (" cutting of the edge of the leaf blade", " general shape of the leaf blade", "the form of leaf blade top ", "gloss of the upper side of the leaf blade", "blisters of leaf blade"," " size of blisters on leaf blade,"'veins of a leaf blade"), four ones defining the shape of the edge of the leaf blade ("waves of leaf blade edge", "cutting of the edge on leaf blade top", "cutting extension of the edge on the leaf blade top", "the stage of cutting of the top edge of the leaf blade"), six ones that determine the colour of the leaf blade ("the tint of the green colour of the leaf blade", "the intensity of the colour of the outside leaves", "the anthocyanin colour of the leaf blade", "the intensity of the anthocyanin colour of the leaf blade", "the distribution of the anthocyanin colour of the leaf blade", "the type of distribution of the anthocyanin colour of the leaf blade"). For the variational analysis of qualitative characteristics that determine the phenotype of the leaf blade, the statistical indices proposed in the work were used [14]: Spirman rank correlation coefficient, $r_{s}$; Friedman dispersion analysis; coefficient of concordation of Kendal, $W$.

Research results. As a result of induced mutagenesis, 17 mutant specimens derived from the leaf lettuce Velmozha (K-7381) (Table 1) were obtained. The analysis of the mutant gene fund was conducted on $\mathrm{M}_{4}$ generation under the conditions of its cultivation in the field in 2014. 
Table 1 - Mutant genotypes of leaf lettuce, obtained from the leaf lettuce variety Velmozha (K7384), received as a result of various mutagenic factors, 2011

\begin{tabular}{|c|c|c|c|}
\hline № & $\begin{array}{l}\text { Mutagenic } \\
\text { factor }\end{array}$ & $\begin{array}{l}\text { Regulations } \\
\text { application }\end{array}$ & $\begin{array}{l}\text { The name of the mutant genotype } \\
\text { is encoded }\end{array}$ \\
\hline 1. & \multirow{3}{*}{-irradiation } & \multirow{3}{*}{$\begin{array}{l}\text { pre-sowing seed } \\
\text { treatment with the } \\
\text { dose of } 7 \mathrm{kP}\end{array}$} & [Velmozha (7 kR)] (K-7400) \\
\hline 2. & & & [Velmozha (7 kR), mf-1] (K-7401(1)) \\
\hline 3. & & & [Velmozha (7 kR), mf-2] (K-7401(2)) \\
\hline 4. & \multirow{3}{*}{$\begin{array}{l}\text { Preparation } \\
\text { DMS }\end{array}$} & \multirow{3}{*}{$\begin{array}{l}\text { pre-sowing seed } \\
\text { treatment with the ex- } \\
\text { position of } 6 \text { hours. }\end{array}$} & [Velmozha (DMS, 6 h.), mf-1] (K-7391(1)) \\
\hline 5. & & & \begin{tabular}{|l} 
[Velmozha (DMS, 6 h.), mf-2] (K-7391(2)) \\
\end{tabular} \\
\hline 6. & & & [Velmozha (DMS, 6 h.), mf-3] (K-7391(3)) \\
\hline 7. & \multirow{2}{*}{$\begin{array}{l}\text { Preparation } \\
\text { DMS }\end{array}$} & \multirow{2}{*}{$\begin{array}{l}\text { pre-sowing seed } \\
\text { treatment with the ex- } \\
\text { position of } 18 \text { hours. }\end{array}$} & [Velmozha (DMS, 18 h.)] (K-7394) \\
\hline 8. & & & [Velmozha (DMS, 18 h.)] (K-7395) \\
\hline 9. & \multirow{7}{*}{$\begin{array}{c}\text { Preparation } \\
\text { DMU-1 }\end{array}$} & \multirow{7}{*}{$\begin{array}{l}\text { pre-sowing seed } \\
\text { treatment with the ex- } \\
\text { position of } 3 \text { hours. }\end{array}$} & [Velmozha (DMU-1, 3 h.), mf-1] (K-7386(1)) \\
\hline 10. & & & [Velmozha (DMU-1, 3 h.), mf-2] (K-7386(2)) \\
\hline 11. & & & [Velmozha (DMU-1, 3 h.)] (K-7387) \\
\hline 12. & & & [Velmozha (DMU-1, 3 h.), mf-1] (K-7412(1)) \\
\hline 13. & & & [Velmozha (DMU-1, 3 h.), mf-2] (K-7412(2)) \\
\hline 14. & & & [Velmozha (DMU-1, 3 h.), mf-3] (K-7412(3)) \\
\hline 15. & & & [Velmozha (DMU-1, 3 h.), mf-4] (K-7412(4)) \\
\hline 16. & $\begin{array}{c}\text { Preparation } \\
\text { DMU-5 }\end{array}$ & $\begin{array}{l}\text { pre-sowing seed } \\
\text { treatment with the ex- } \\
\text { position of } 6 \text { hours. }\end{array}$ & [Velmozha (DMU-5, 6 h.)] (K-7418) \\
\hline
\end{tabular}

The mutant leaf lettuce gene fund derived from Velmozha variety (K-7384) was represented only by the genotypes formed as a result of -irradiation at a dose of $7 \mathrm{kP}$ (physical mutagenic factor) and the action of DMS, DMU-1 and DMU-5 preparations in different time exposures of pre-sowing seed treatment 3, 6 and 18 hours (chemical mutagenic factor) (Table 1). According to the data obtained on mutant samples derived from Velmozha variety (K-7384), it was found that among the 17 investigated qualitative traits, which determine the phenotype of the leaf blade, 2 traits had 5 levels of manifestation, 4 traits -4 levels of manifestation, 7 traits -3 levels of manifestation, 2 traits -2 levels of manifestation and 2 traits 1 level of manifestation. As a result of induced mutagenesis action, the greatest variability in manifestation was attributed to the "shape of the leaf blade" and "the intensity of the anthocyanin colouring of the leaf blade". Practically there was no change in the trait of "the cut-off edge of the leaf blade" and the trait "the vein of the leaf blade". A group of 7 traits that determine the morphology of the leaf blade and its veining had 21 levels of manifestation. A group of 6 traits that determine the colour of the leaf blade has 20 degrees of manifestation. A group of 4 traits that determine the shape of the edge of the leaf blade had 12 stages of manifestation.

In order to assess the differences between the mutant forms and the original form of the leaf lettuce variety Velmozha (K-7381) by quality traits , Friedman ranked variance analysis, Kendal concordation coefficient and Spearman rank correlation coefficient were used. The comparison of mutant samples and the original form was conducted by above mentioned criteria through the comparison with the average traits in the experiment.

The results of calculations are summarized in Table 2. The obtained data showed the difference between the original form and the forms derived from it by mutant genotypes by the morphogenesis of the association of traits that determine the phenotype of the leaf blade. One of the criteria of difference by the integral expression of a set of traits in the investigated samples of mutant forms is a comparison of 
the sum of ranks $(\mathrm{Si})$ with the experimental value of the criterion ${ }^{2}$ [14]. Namely, if there are cases when $S_{i}>{ }^{2}$, then this inequality solution is a proof of the mutant genotypes presence, different from the original variety. In our case, ${ }^{2}=53,74$, while the scale of the variation of the index "sum of ranks $\left(S_{i}\right)$ " was $93,0-$ 226,50 , that is, in the experiment there were significant, experimentally proved differences between the mutant and the original forms of the investigated association of qualitative traits (Table 2). At the same time, the calculation of the Kendal concordance coefficient $(W=0,198)$ showed the presence of a slight coordination of morphogenetic processes that preceded the block of formed associative traits and the presence of significant specificity.

A more expressed assessment of the differences between the mutant genotypes and the original form, Velmozha variety (K-7381), is given by the index "average index for the sample" of Friedman's dispersion analysis and the value of the Spirman rank correlation coefficient $\left(r_{s}\right)$. According to the data of Table 2, the paired values of this coefficient between the original form and the mutant genotypes varied from $-0,17$ to 0,94 , and the index "average index for the sample" ranged from 1,24 to 4,41 . In this case, the mutant genotypes most closely related to the original form had the following, statistically significant values of the Spearman rank correlation coefficient: [Velmozha (DMS, 6 h.), mf-1] (K-7391 (1)) $\left(r_{s}=0.79\right)$; [Velmozha (7 kP), mf-1] (K-7401 (1)) ( $\left.r_{s}=0.79\right)$; [Velmozha (DMU-1, 3 h.), mf-1] (K-7386 (1)) $\left(r_{s}=0.94\right)$; [Velmozha (DMU-1, $3 \mathrm{~h}$.), mf-2] (K-7412 (2)) ( $\left.r_{s}=0.94\right)$. The variation of the average sample indices of most of the mutant samples was within the error margin of the mean index corresponding to Velmozha variety (K7381). An exception is the mutant sample [Velmozha (DMU-1, 3 h.), mf-2] (K-7386 (2)), for which the Spirman rank correlation coefficient showed an average link between it and the original form $\left(r_{s}=0,43\right)$ by the association of qualitative traits.

After establishing the traits of manifestation of qualitative traits that determine the phenotype of the leaf blade, a correlation analysis was carried out between these traits and quantitative economic and valuable ones. In total 6 quantitative traits were involved in the correlation analysis: "height of the rosette of plants"; "plant rosette width", "number of leaves per plant"; "the largest length of the leaf"; "the largest leaf width"; "crop capacity". The integral criterion of the variability of qualitative traits for a certain sample of lettuce was the index "average index for sampling". During the correlation analysis, this indicator was compared with the corresponding quantitative traits of plants of the same sample of leaf lettuce. For the analysis, not only mutant samples were used, but also the original form from which they were derived.

The formation of the database of quantitative traits was carried out on the basis of the results of threeyear (2012-2014) biometric measurements in the field conditions of the growth parameters of the leaf lettuce both of original and derived mutant samples of generation $\mathrm{M}_{2}-\mathrm{M}_{4}$. Data concerning this breeding experiment are reflected in the work [15]. According to the data obtained, for the group of phylogenetically related genotypes, which was created by Velmozha variety (K-7485) and its 16 mutant genotypes derived from it was the value of the Spirman rank correlation coefficient between the index "average index for the sample" and one quantitative trait "the number of leaves on one plant " $\left(r_{s}=-0,49\right)$.

A middle maturing, friendly-maturing, high-yielding and drought resistant variety Patriot received from the mutant sample [Velmozha $(7 \mathrm{kR})](\mathrm{K}-7400)]$ was given for the qualification testing to the system of state varieties trial in 2015 year according to the results evaluation of the complex of valuable quantitative traits of the leaf lettuce mutant samples. A comparative analysis of the manifestation of economically valuable quantitative traits in Patriot variety and Standard Snizhynka variety, conducted during 20152017, revealed a number of advantages over the latter. The number of days during the period from mass germination to marketable maturity in the new variety makes 17-18 days, in the standard variety Snizhynka is $20-23$ days. The content of dry matter is $5.33 \%$, total sugar is $0.75 \%$, vitamin C $-26.12 \mathrm{mg} /$ $100 \mathrm{~g}$, nitrates $-248.5 \mathrm{mg} / \mathrm{kg}$ (at the permissible rate of $2000 \mathrm{mg} / \mathrm{kg}$ under cultivation in field conditions). The crop capacity is 11,92 at $6,14 \mathrm{t} /$ ha in the variety standard. 
Table 2 - Results of calculation by nonparametric statistics methods of manifestation peculiarities of the association of qualitative traits that determine morphology, veining, edge shape and colouring of the leaf blade of mutant samples derived from the leaf lettuce variety Velmozha (K-7381)

\begin{tabular}{|c|c|c|c|c|c|c|c|}
\hline \multirow[b]{2}{*}{ № } & \multirow[b]{2}{*}{ Mutant sample } & \multirow[b]{2}{*}{ № of cat. } & \multicolumn{4}{|c|}{ Results of Rank Fridman Dispersion Analysis } & \multirow{2}{*}{$\begin{array}{l}\text { Spirman's rank cor- } \\
\text { relation coefficient, } r_{p} \\
\text { * }\end{array}$} \\
\hline & & & average rank & $\begin{array}{l}\text { amount of } \\
\text { ranks, } S_{i}\end{array}$ & $\begin{array}{l}\text { average in- } \\
\text { dex for the } \\
\text { sample }\end{array}$ & $\begin{array}{c}\text { medium-quadratic } \\
\text { deviation }\end{array}$ & \\
\hline 1. & Velmozha variety & K-7381 & 11,27 & 191,5 & 3,53 & 2,92 & - \\
\hline 2. & Velmozha (DMS, 6 h.), mf-1 & K-7391(1) & 9,21 & 156,5 & 2,59 & 2,55 & 0,79 \\
\hline 3. & Velmozha (DMS, 6 h.), mf-2 & $\mathrm{K}-7391(2)$ & 7,24 & 123,0 & 1,77 & 2,11 & 0,45 \\
\hline 4. & Velmozha (DMS, 6 h.), mf-3 & K-7391(3) & 10,59 & 180,0 & 3,59 & 2,70 & 0,45 \\
\hline 5. & Velmozha (DMS, 18 h.) & K-7394 & 6,18 & 105,0 & 1,53 & 1,67 & 0,43 \\
\hline 6. & Velmozha (DMS, 18 h.) & K-7395 & 8,29 & 141,0 & 2,47 & 2,81 & 0,33 \\
\hline 7. & Velmozha (DMU-1, 3 h.), mf-1 & K-7386(1) & 9,68 & 164,5 & 2,77 & 2,39 & 0,94 \\
\hline 8. & Velmozha (DMU-1, 3 h.), mf-2 & K-7386(2) & 5,47 & 93,0 & 1,24 & 1,15 & 0,43 \\
\hline 9. & Velmozha (DMU-1, 3 h.) & K-7387 & 9,53 & 162,0 & 3,18 & 2,88 & $-0,17$ \\
\hline 10. & Velmozha (DMU-1, 3 h.), mf-1 & K-7412(1) & 7,44 & 126,5 & 1,94 & 2,28 & 0,32 \\
\hline 11. & Velmozha (DMU-1, 3 h.), mf-2 & $\mathrm{K}-7412(2)$ & 8,82 & 150,0 & 2,65 & 2,37 & 0,94 \\
\hline 12. & Velmozha (DMU-1, 3 h.), mf-3 & K-7412(3) & 13,32 & 226,5 & 4,41 & 3,0 & 0,41 \\
\hline 13. & Velmozha (DMU-1, 3 h.), mf-4 & K-7412(4) & 8,86 & 150,5 & 2,77 & 2,54 & $-0,01$ \\
\hline 14. & Velmozha (DMU-5, 6 h.) & K-7418 & 8,68 & 147,5 & 2,77 & 2,53 & $-0,12$ \\
\hline 15. & Velmozha (7 kR) & K-7400 & 8,68 & 147,5 & 2,77 & 2,54 & $-0,12$ \\
\hline 16. & Velmozha (7 kR), mf-1 & K-7401(1) & 10,35 & 176,0 & 3,24 & 2,82 & 0,79 \\
\hline 17. & Velmozha (7 kR), mf-2 & $\mathrm{K}-7401(2)$ & 9,41 & 160,0 & 3,12 & 2,78 & $-0,04$ \\
\hline
\end{tabular}




\section{Conclusions and perspectives of further researches in this direction}

It was determined that by the manifestation of the association of traits that determine the phenotype of the leaf blade, 5 mutant specimens appeared to be the most contrasting in comparison with the original form: [Velmozha (7 kR)] (K-7400); [Velmozha (7 kP), mf-2] (K-7401 (2)); [Velmozha (DMU-1, 3 h.)] (K7387); [Velmozha (DMU-1, 3 h.), mf-4] (K-7412 (4)); [Velmozha (DMU-5, 6 h.)] (K-7418) formed as a result of -irradiation and seed treatment with DMU-1 and DMU-5 preparations before sowing. The effect of -irradiation, DMU-1 and DMU-5 preparations initiated the formation of 4 mutant specimens with a strong correlation $\left(r_{s}>0.6\right)$ with the initial form: [Velmozha (7 kR), mf-1] (K-7401 (1)); [Velmozha (DMS, 6 h.), mf-1] (K-7391 (1)); [Velmozha (DMU-1, 3 h.), mf-1] (K-7386 (1)); [Velmozha (DMU-1, 3 h.), mf-2] (K-7412 (2)). The correlation connections between the integral indicator of the set of qualitative traits "average index for the sample" and the level of the quantitative sign "number of leaves per plant" $\left(r_{s}=-0,49\right)$ are determined. It will allow to select high-yield genotypes of leaf lettuce in the early stages of ontogenesis of plants by association of qualitative traits that determine the phenotype of the leaf blade in further selection work. On the basis of the mutant gene fund, a new high-yielding variety of leaf lettuce Patriot straw variety, derived from the mutant sample [Velmozha(7 KP)] (K-7400) was developed.

\section{References.}

1. Yakovenko K.I. (2000). Ovochivnytstvo Ukrainy na porozi KhKhl stolittia. [Vegetable Ukraine on the threshold of the XXI century]. Visnyk ahrarnoi nauky. No 8. P. 21 - 22. [In Ukrainian].

2. Ruchkin O.V. (1999). Napriam rozvytku vyrobnytstva ta realizatsii produktsii ovochivnytstva i bashtannytstva $v$ Ukraini $v$ umovakh rynku. [The direction of development and production of vegetable and melon products in Ukraine in the market conditions]. Ovochivnytstvo i bashtannytstvo. No 44. P. 3 7. [In Ukrainian].

3. Bondarenko H.L., Yakovenko K.I. (Eds.). (2001). Metodyka doslidnoi spravy v ovochivnytstvi i bashtannytstvi. [Methodology of experimental work in vegetable and melon]. Kharkiv: Osnova. 369 p. [In Ukrainian].

4. Pivovarov V.F., Dobrutskaya E.G. (2000). Ekologicheskie osnovy selektsii i semenovodstva ovoshchnykh kul'tur. [Ecological bases of selection and seed-growing of vegetable cultures]. Moskva. 197 p. [In Russian].

5. Mou B. (2011). Mutations in lettuce improvement. International Journal of Plant Genomics. Article ID 723518, 7 pages. doi: $10.1155 / 2011 / 723518$

6. Huo H., Henry I.M., Coppoolse E.R. (2016). Rapid identification of lettuce seed germination mutants by bulked segregant analysis and whole genome sequencing. The Plant Journal. V. 88/3. doi.org/10.1111/tpj.13267

7. Parry M.A., Madgwick P.J. Bayon C. et al. (2009). Mutation discovery for crop improvement. J. of Experimental Botany. V. 60. P. $2817-2825$.

8. Grube R.C., Ochoa O.E. (2005). Comparative genetic analysis of field resistance to downy mildew in lettuce the cultivars «Grand Rapids» and «lce berg». Euphytica. V. 142. P. $205-215$.

9. Delia Marcu, Victoria Cristea, Liviu Daraban. (2012). Dose-dependent effects of gamma radiation on lettuce (Lactuca sativa var. capitata) seedlings. International J. of Radiotion Biology. October 2012. P. 219 - 223. doi.org/10.3109/09553002.2013. 734946.

10. Wi S.G., Chung B.Y., Kim J.S. et al. (2007). Effects of gamma irradiation on morphological changes and biological responses in plants. Micron. V. 38. P. $553-564$.

11. Horova T.K., Yakovenko K.I. (Eds.). (2001). Suchasni metody selektsii ovochevykh i bashtannykh kultur. [Modern methods of selection of vegetable and melon cultures]. Kharkiv: Osnova. 432 p. [In Ukrainian].

12. Yakovenko K.I. (Ed.). (2001). Suchasni tekhnolohii v ovochivnytstvi. [Modern technologies in vegetable growing ]. Kharkiv: IOB UAAN, 128 p. [In Ukrainian].

13. Leshchuk N.V. (2007). Metodyka provedennia ekspertyzy sortiv salatu posivnoho (Lactuca sativa L.) na vidminnist, odnoridnist i stabilnist. [Method of conducting examination of varieties of lettuce (Lac- 
tuca sativa L.) for difference, homogeneity and stability]. Okhorona prav na sorty roslyn: ofits. biul. Kyiv: Alefa, Vyp. 3, ch. 2/2007. P. 366 - 379. [In Ukrainian].

14. Litun P.P., Kyrychenko V.V., Petrenkova V.P. et al. (2009). Systemnyi analiz v selektsii polovykh kultur: navchalnyi posibnyk. [System analysis in field crop selection: tutorial]. Kharkiv: In-t roslynnytstva im. V.la. Yurieva UAAN. 351 p. [In Ukrainian].

15. Kondratenko S.I., Mytenko I.M. (2018). Rezultaty selektsiinoi roboty zi stvorennia vysoko adaptyvnykh sortiv salatu posivnoho lystkovoho (Lactuca sativa var. secalina L.). [The results of breeding work on the creation of highly adaptive varieties of lettuce (Lactuca sativa var. Secalina L.) salad.]. Visnyk KhNAU. Ser. "Roslynnytstvo, selektsiia i nasinnytstvo, ovochivnytstvo». No 1. P. 113 - 124. [In Ukrainian]. 